\title{
Memahami Eksistensi dan Adaptasi Masyarakat Bersuku Batak Di Kota Semarang
}

\author{
Anggi Anggraini \\ (nonangoe@gmail.com) \\ (Mahasiswi Ilmu Komunikasi Universitas Semarang)
}

\begin{abstract}
Anggi Anggraini, G.311.10.0011. Understanding the existence and the adaptation of Batak tribe people in Semarang: (Case study of Batak tribe in Semarang). Essay: S1 Majoring Communication of Universitas Semarang.

This research intended to discover adaptation process and the existence of Batak tribe in Semarang as minority. Furthermore, this research could be used to break the ice of tension between Batak tribe and Java tribe, if there was any barrier before.

The method is qualitative descriptive, in collecting data the researcher used observation and indepth interviews. Batak in Semarang is minority, but it doesn't mean omitting its indigenous culture because of their settlement in new place, which is in Semarang. The existence of Batak culture is still going strong and supporting to adapt well. All of that is solely to receive positive recognition from the Java tribe, and demonstrate its strong sense of brotherhood.
\end{abstract}

Kata Kunci : Eksistensi, Adaptasi, Suku Batak

\section{Pendahuluan}

Banyaknya perpindahan

penduduk dari berbagai daerah, memerlukan sebuah proses komunikasi antar budaya antar individu. Salah satunya seperti komunikasi antar budaya Batak yang berpindah ke Semarang, dengan masyarakat Jawa. Sebagai golongan minoritas, Batak harus berjuang mempertahankan segala adat budaya, tradisi, kebiasaan yang mereka bawa dari tanah kelahiran mereka. Hal itu semata-mata dilakukan juga untuk mengurangi respon negatif yang dapat berimbas diskriminatif oleh suku Jawa, yang sebelumnya memandang orang bersuku Batak beserta kebudayaan yang mereka miliki tidak selaras dengan budaya Jawa.

Adanya berbagai perbedaan pendapat yang timbul karena adanya bedanya sudut pandang antara dua suku tersebut, dan berimbas pada beberapa hal, misalnya saja sikap stereotipe.
Stereotipe membuat orang hanya dapat menilai orang lain dengan kebudayaan yang berbeda hanya berdasarkan garis besar kelompok orang lain tersebut dapat dikategorikan, bahkan sikap ini juga tidak memadai karena stereotipe adalah generalisasi berdasarkan pengalaman yang terbatas saja (Deddy Mulyana, 2006: 256-257).

Indonesia merupakan negara yang multietnis karena terdiri dari berbagai macam suku bangsa. Setiap suku bangsa memiliki adat istiadat yang berbeda satu sama lain. Perbedaan tersebut dapat dilihat dari sistem kekerabatan, sistem kesenian, sistem kepercayaan atau nilai-nilai budayanya yang ada. Berdasarkan perbedaanperbedaan tersebut, maka setiap suku adalah unik dan memiliki ciri khas tersendiri yang tidak dimiliki oleh suku yang lainnya. Ciri khas suatu suku akan melekat pada seorang yang berasal dari 
suku tersebut dan akan terus dilestarikan secara turun menurun, dari generasi ke generasi.

Pengertian paling tua atas kebudayaan di ajukan oleh Edward Burnett Tylor (dalam Alo Liliweri, 2007: 107) bahwa: 'kebudayaan adalah kompleks dari keseluruhan pengetahuan, kepercayaan, seni, hukum, adat istiadat, bahasa, dan setiap kegiatan lain yang dimiliki oleh manusia sebagai anggota suatu masyarakat.'

\section{Tinjauan Pustaka}

\section{A. Standpoint Theory}

Standpoint bisa dipahami
sebagai posisi seseorang yang
didasarkan pada lokasi sosial. Teori ini memberikan kerangka untuk memahami sistem kekuasaan. Kerangka ini dibangun atas dasar pengetahuan yang dihasilkan dari kehidupan sehari-hari orang, mengakui bahwa individuindividu adalah konsumen aktif dari realitas mereka sendiri, dan bahwa individu-individu itu sendiri merupakan sumber informasi yang paling penting mengenai pengalaman mereka (West dan Turner, 2007: 499).

Teori Standpoint memberikan kewenangan kepada suara pribadi individu, menegaskan bahwa pengalaman, pengetahuan, dan perilaku komunikasi orang sebagian besar dibentuk oleh kelompok sosial dimana mereka bergabung. Teori Standpoint mengilustrasikan sentralitas komunikasi dalam membentuk dan menyalurkan sikap serta menunjuk pada kegunaan komunikasi sebagai alat untuk mengubah status quo dan memproduksi perubahan (West dan Turner, 2007: 508-509).

Sesuatu yang penting dalam teori ini, adalah adanya pemahaman yang berlapis, dimana kita memiliki lebih dari satu identitas yang membentuk sudut pandang dalam diri yang unik, termasuk didalamnya ada ras, kelas sosial, gender, dan lain sebagainya.

\section{B. Etnosentrisme}

Etnosentrisme adalah akar rasisme. Etnosentrisme yaitu kecenderungan memandang orang lain secara tidak sadar dengan menggunakan kelompok kita sendiri dan kebiasaan kita sendiri sebagai kriteria untuk segala penilaian. (Deddy Mulyana, 2006: 254). Oleh sebab itu dalam teori ini, semakin banyak atau besar kesamaan kita dan orang lain, maka akan semakin dekat, begitu pula sebaliknya.

Dalam konsep ini kita melihat kita sendiri, budaya, kelompok kita sebagai yang paling baik, paling bermoral, paling benar. Pandangan ini adalah posisi mutlak yang menaifkan posisi lain dari tempatnya (Porter dan Samovar dalam Deddy Mulyana, 2006: 254).

Dalam etnosentrisme, setiap kelompok merasa yang ia jalani dan miliki lebih unggul dari pada kelompok selain ia. Terdapat juga korelasi antara etnosentrisme dan solidaritas kelompok, dimana apabila semakin besar etnosentrisme sebuah kelompok, maka semakin besar solidaritas kelompok itu (Alo Liliweri, 2011: 169).

Selain membimbing para anggota dari sebuah kelompok etnik untuk memandang kebudayaan mereka sebagai yang terbaik dari kelompok etnik lainnya, etnosentrisme juga menyebabkan prasangka dalam setiap kelompok untuk memandang kelompok lain bisa jadi sebagai kafir, buruk, tidak beradab, dan lain sebagainya.

\section{Stereotipe \\ Stereotipe adalah konsep penilaian terhadap seseorang hanya}


berdasarkan persepsi terhadap kelompok di mana orang tersebut dapat dikategorikan. Stereotipe dapat berupa prasangka positif dan juga negatif, dan kadang-kadang dijadikan alasan untuk melakukan tindakan diskriminatif. Menurut Hamilton (dalam Deddy Mulyana, 2006: 256-257), bahwa sikap stereotipe ini dapat menekankan bahwa disamping menciptakan ekspetasi mengenai bagaimana orang akan berprilaku, streteotipe sering akan menimbulkan perbuatan yang berupa tindakan atas dasar informasi yang kita percayai sebagai benar.

Stereotipe budaya terkenal sangat mudah dibuat. Peoples dan Bailey (dalam Larry A. Samovar, 2010: 50) mengungkapkan, "Setiap masyarakat memiliki strereotipe mengenai anggota, etika, dan kelompok rasial dari masyarakat yang lain". Ketika diulang beberapa kali, hal itu menjadi stenografi yang mewakili sekelompok orang.

Gerungen (dalam Alo Liliweri, 2011: 177) menyimpulkan bahwa, strereotipe mengenai orang lain sudah terbentuk pada orang yang berprasangka sebelum ia mempunyai kesempatan untuk bergaul sewajarnya dengan orang-orang lain yang dikenakan prasangka itu. Maka dari itulah, jika komunikasi di antara mereka yang berbeda etnik didahului oleh stereotipe yang negatif antar etnik, pada akhirnya akan mempengaruhi evektifitas komunikasi.

D. Adaptasi dan Eksistensi Pendekatan

mengharuskan individu untuk menyaring manakah perilaku yang harus atau yang tidak harus dia lakukan. Adaptasi nilai dan norma antarpribadi termasuk antarbudaya sangat ditentukan oleh dua faktor, yakni pilihan untuk mengadaptasika nilai dan norma yang fungsional atau mendukung hubungan antar pribadi (Alo Liliweri, 2007: 63).

Beradaptasi juga berkaitan dengan bereksistensi, karena selain memerlukan rasa nyaman di lingkungan baru untuk beradaptasi, individu memerlukan rasa aman dengan tidak mengubah identitas dirinya. Eksistensi yang bisa dipahami sebagai keberadaan, memerlukan ruang dikehidupan individu untuk menjaga self-identity mereka ditengah kehidupan baru yang mungkin akan berbeda latar belakang dengan kehidupannya yang sebelumnya (Engkus Kusrwano, 2008: 23).

Dalam alur komunikasi antarbudaya, seorang ahli budaya mengemukakan bahwa 'Bagi orang asing, pola budaya kelompok yang dimasukinya bukanlah merupakan tempat berteduh, tapi merupakan suatu arena petualangan, bukan merupakan hal yang lazim tapi suatu topik penyelidikan yang meragukan, bukan suatu alat untuk lepas dari situasisituasi problematik, tapi merupakan suatu situasi problematik tersendiri yang sulit dikuasai' (Schutz dalam Deddy M, 2010: 138).

\section{Metodologi Penelitian}

Penelitian ini mengambil jenis penelitian deskriptif kualitatif. Dengan penelitian ini, di harapkan mampu memberikan informasi deskriptif kualitatif dengan lebih terjabar. Penulis menggunakan data primer dan data sekunder. Data primer merupakan sumber data penelitian yang diperoleh secara langsung dari sumber asli yang berupa kata-kata serta tindakan (Lofland dalam Lexy J. Moleong, 2005: 157). Sumber data primer yang Penulis gunakan adalah warga suku Batak dari Sumatera Uara yang berdomisili di kota Semarang, serta warga suku Jawa asli yang juga berdomisili di kota Semarang. 
Sementara itu, data sekunder merupakan data tambahan yang diperoleh dari catatan-catatan dokumen dan juga sumber kepustakaan (Lofland dalam Lexy J. Moleong, 2005: 157). Data sekunder Penulis peroleh dari berbagai media, seperti buku-buku, $e$ book mengenai hal yang bersangkutan, serta membaca beberapa arsip-arsip untuk menambah wawasan Penulis mengenai penelitian ini.

Penelitian ini menggunakan cuplikan yang bersifat selektif, dengan menggunakan pertimbangan berdasarkan konsep teoritis yang digunakan, keinginan pribadi dari Penulis, dan lain sebagainya. Oleh sebab itu, penelitian ini bersifat purposive sampling. Penelitian yang bersifat purposive sampling memiliki cara meneliti dengan selektif, juga berdasarkan pada konsep teoritis yang digunakan, keinginan pribadi dari Penulis, dan lainnya. Tujuan dari penelitian sejenis ini adalah untuk mendalami data sehubungan dengan tidak adanya realitas tunggal (Goetz dan LeCompte dalam Gunawan, 2002: 36).

\section{Hasil dan Pembahasan}

Pada bab ini Peneliti akan memaparkan hasil penelitian yang Peneliti lakukan, yakni observasi dan wawancara mendalam terkait dengan perumusan masalah yang dituliskan di bab 1. Narasumber yang telah disaring oleh Peneliti merupakan suku Batak Toba, karena suku Batak Toba merupakan suku Batak terbanyak, yang tergabung dalam komunitas Parhata, yakni komunitas anak Batak di kampus Universitas Diponegoro, serta beberapa jamaah Gereja HKBP, yakni gereja adat Batak. Selain itu Peneliti juga mewawancarai warga Semarang bersuku Jawa asli, dan narasumber ahli yang bergerak dalam bidang budaya.
Penelitian yang dilakukan oleh Peneliti di Kota Semarang mengenai budaya masyarakat Batak sebagai suku minoritas, menyorot ke beberapa hal sebagai poin pembahasan. Yaitu mengenai adat, proses adaptasi, bahasa, habit dan ciri khas. Dari penelitian ini, diketahui bahwa suku Batak yang berdomisili di Kota Semarang ini tetap menjalankan dan melaksanakan berbagai adatnya, walaupun sebagai suku yang minoritas. Hanya saja, adatadat yang mereka lakukan tidak secara terang-terangan seperti yang biasa mereka lakukan di kampung halamannya.

Salah satu kebudayaan yang cenderung berlawanan bila dihadapkan dengan kebudayaan Jawa ini juga memiliki tempat beribadah sendiri, Gereja HKBP yang ada kawasan Pleburan dan juga Semarang Barat. Gereja-gereja mereka biasanya dijadikan tempat perkumpulan untuk melakukan kegiatan adat mereka, juga tempat beribadah dan pertemuan keluarga Batak.

Selain itu, pola komunikasi mereka yang khas juga masih terjaga. Sebagian besar masih saling menggunakan bahasa Batak saat berinteraksi. Walaupun sebagian kecil yang lain menggunakan bahasa Indonesia, namun logat yang khas dari suku Batak ini tetap mereka gunakan. Merupakan sebuah kebanggan bagi mereka yang bersuku Batak untuk terus menggunakan bahasa Batak, di kota Semarang yang dihuni oleh masyarakat pribumi jawa yang dalam kehidupan sehari-harinya aktif berbahasa Jawa. Walaupun tidak jarang warga Batak harus mendapatkan dugaan negatif karena berkomunikasi menggunakan bahasa Batak. Nada yang tinggi, cara bicara yang cepat, tatapan mata yang tajam membuat mereka sering kali dianggap sebagai orang yang kejam dan 
kasar. Namun, dugaan seperti itu dapat luntur saat komunikasi antar warga bersuku Batak terhadap warga bersuku lainnya menjadi lebih intens.

Disisi lain, ternyata warga Batak juga masih aktif melestarikan kebudayaannya dengan cara informal, dengan cara bernyanyi misalnya. Tidak hanya di acara-acara kebudayaan saja mereka melakukan tarian, nyanyian, namun juga disaat mereka berkumpul walaupun hanya sekedar berkumpul menghabiskan waktu bersama teman. Mereka bersenandung bersama menyanyikan lagu-lagu Batak, saling bertukar cerita yang tidak pernah terputus tentang kebudayaan Batak. Juga dalam acara-acara kelompok atau komunitas, yang tetap melakukan tarian tor-tor misalnya. Semua tetap terjaga, dan tetap aktif dilestarikan.

Berdasarkan observasi yang Peneliti lakukan, Peneliti juga melihat adanya kedekatan dari warga Batak dengan warga Jawa, yang saling menghargai satu sama lain. Faktor yang ada dibalik kedekatan mereka salah satunya adalah rasa ingin tahu mengenai kebudayaan suku lain yang dipandang menarik. Dimulai dari pengenalan terhadap teman-teman dekat ini lah warga Batak melakukan proses pengenalan kebudayaan mereka.

Dalam standpoint theory, ada sistem kekuasaan yang terbentuk dan juga memperkenalkan bagian-bagian dari kekuatan identitas. Selain itu, mereka (orang Jawa) juga menilai orang Batak pada dasarnya semua sama, karena mereka tergabung dalam satu kesatuan yang serupa, yaitu bersuku Batak. Dan pengalaman-pengalaman yang orang Jawa dapatkan baik secara langsung maupun tidak langsung, akan membentuk pola pikir mengenai seperti apa orang Batak, dan menyalurkannya melalui sikap dan kemampuannya berinteraksi verbal maupun nonverbal dengan orang Batak.

Tidak salah lagi jika rasisme seperti ini berawal dari sikap etnosentrisme yang sebelumnya sudah tumbuh. Mereka menggunakan suku mereka sebagai landasan dari semua kriteria yang mereka lihat terhadap orang lain. Etnosentrisme jika dikaji lebih mendalam, akan tepat jika diperuntukkan bagi asumsi kesamaan realitas tunggal dalam konteks budaya. Ditambah lagi, Jawa sebagai suku dominan, memiliki kekuatan lebih daripada Batak yang minoritas di kota Semarang. Batak telah melakukan caracara halus maupun keras untuk memperkenalkan kebudayaan Batak kepada lingkungan baru mereka, Jawa. Mulai melalui cerita, nyanyian, bahkan mengajak Jawa untuk bergabung. Namun tidak semua mendapat tanggapan positif. Hal itu karena masih adanya dugaan-dugaan negatif yang mengakar di benak Jawa mengenai Batak beserta adatnya yang tidak sebanding lurus dengan Jawa dan adat Jawa.

Sikap etnosentrisme yang timbul, baik dari suku manapun, yang menyebutkan bahwa baik suku, adat, bahasa, atau apapun yang ia miliki adalah standar segala kriteria yang ia nilai terhadap orang lain, adalah lumrah, tetapi merupakan sebuah kebiasaan buruk yang harus dibenahi. Untuk menyeimbangkan etnosentrisme, dibutuhkan etika kedaifan dan toleransi. Etika kedaifan, membuat seorang individu akan sadar betapa lemahnya dia tanpa orang lain, tanpa pandang suku. Ia akan menyadari bahwa ia hidup sebagai makhluk sosial, yang membutuhkan orang lain, dan mengesampingkan ego untuk memperburuk citra suku lain dibandingkan dengan sukunya. Selanjutnya adalah toleransi, dimana 
toleransi yang sudah ada harus diasah, untuk mempertajam rasa persaudaraan kita terhadap siapapun, atas dasar Bhineka Tunggal Ika.

\section{Penutup}

Penelitian yang Penulis tuliskan mengenai eksistensi dan adaptasi suku Batak di Semarang, sebenarnya bertujuan untuk menyadarkan masyarakat terhadap keragaman budaya Indonesia.

Berdasarkan pengamatan

Peneliti selama melakukan observasi, berikut dengan wawancara mendalam terhadap beberapa narasumber, termasuk narasumber ahli, Peneliti menyimpulkan bahwa orang Jawa dan Batak sebenarnya tidak memiliki masalah yang signifikan dalam bergaul. Hanya saja, perbedaan karakter di kedua suku ini menjadi alasan dari sikap-sikap yang memicu permasalahan antar budaya. Dengan demikian, dapat dinyatakan bahwa cara memandang kedua suku ini diambil dari sisi yang berbeda. Hal itu wajar, karena adanya perbedaan latar belakang budaya yang bertolak belakang.

Individu yang menyamaratakan semua orang di sebuah suku, sebenarnya adalah yang terisolasi dari kehidupan. Ia terlalu menutup diri, terhadap orang-orang yang berbeda latar belakang dengannya, sehingga menganggap semua orang adalah sama, berdasarkan sedikit pengetahuan yang ia miliki. Hal itu justru akan membuatnya tidak berkembang dan akan mempersulitnya dalam bergaul. Disini mungkin ia akan kesulitan berkomunikasi dalam tahap komunikasi kelompok, bahkan komunikasi intrapersonal.

Tidak ada perbedaan suku manapun saat beradaptasi di lingkungannya yang baru. Saat individu bersuku Batak bertandang ke Semarang, dan berdomisili di Semarang, adaptasi beserta kendala yang muncul akan sama halnya saat seorang bersuku Jawa berpindah tempat tinggal ke Medan. Hal itu dikarenakan faktor perbedaan jumlah individu, dimana ada satu suku yang mayoritas sehingga mempunyai kekuatan lebih, dan memaksa suku lain yang minoritas mau tidak mau mengalah untuk menyodorkan dirinya sebagai bentuk penyesuaian.

Bagi calon peneliti lain, dapat menggunakan tema yang sama dengan Penulis, namun dapat dilakukan dengan metode yang lebih spesifik, misalnya dengan etnografi, agar hasil dari penelitian tersebut dapat dijabarkan lebih terperinci.

\section{DAFTAR PUSTAKA}

Alo Liliweri. 2007. Dasar-Dasar Komunikasi Antar Budaya. Yogyakarta : Pustaka Pelajar. 2011. Gatra-Gatra Komunikasi Antar Budaya. Yogyakarta : Pustaka Pelajar.

Deddy Mulyana. 2006. Ilmu Komunikasi Suatu Pengantar. Bandung : Remaja Rosdakarya.

Antar Budaya. Bandung : Remaja Rosdakarya.

Gunawan Witjaksana. 2005, PokokPokok Pikiran dalam Metode Penelitian Komunikasi Kualitatif. Buku ajar Ilmu Komunikasi USM.

Larry A. Samovar., Richard E. Porter., \& Edwin R. McDaniel. 2010. Komunikasi Lintas Budaya (Edisi terjemahan oleh Indri Margaretha Sidabalok). Jakarta : Salemba Humanika. 
Lexy J. Moleong. 2005. Metode Penelitian Kualitatif (Edisi Revisi). Bandung : PT. Remaja Rosdakarya.
West, R., \& Turner, L. 2007. Introducing Communication Theory (3rd ed). Singapore : McGraw Hill International. 